\title{
Gregory of Nyssa's Life of Gregory Thaumaturgus and the Conversion of Neocaesarea
}

\author{
Byron MacDougall \\ Institut für Byzantinistik und Neogräzistik, Universität Wien \\ byron.macdougall@gmail.com
}

\begin{abstract}
Gregory of Nyssa's Life of Gregory Thaumaturgus concludes with a scene describing how the people of Neocaesarea, while crowding together at a festival in the city's theatre, bring a plague upon themselves by praying to their ancestral god. The prayer uttered by the citizens is itself a text from Isaiah in the Septuagint, and moreover a verse which Gregory of Nyssa expounds in one of his homilies. Gregory's exegesis of that verse in the homily reveals the significance of the same verse's appearance in the Life's conversion narrative. In the Life, Gregory Thaumaturgus stops the plague, and his behavior evokes a subsequent verse from Isaiah with a soteriological meaning of its own. The account of the conversion of Neocaesarea, a scene which has otherwise puzzled commentators, is thus structured so that its people and Gregory Thaumaturgus together dramatize Isaiah's prophecy of universal salvation as it was understood in Christian exegesis.
\end{abstract}

\section{Keywords}

Gregory of Nyssa - Gregory Thaumaturgus - conversion - Isaiah - Pontus - festival

Gregory of Nyssa's Life of Gregory Thaumaturgus concludes with an event that took place early in the saint's career and which marked the beginning of his Christianization of the people in Neocaesarea and in the Pontic countryside. ${ }^{1}$

1 For the text of the Life, I use the section and line numbers of Pierre Maraval's edition and translation: Grégoire de Nysse, Éloge de Grégoire le Thaumaturge, Éloge de Basile (sc, 573), Paris, 2014. In this Maraval reprints Heil's text from Gregorii Nysseni Sermones, Pars II, ed. G. Heil, J. Cavarnos, O. Lendle, in: Gregorii Nysseni Opera, Vol. X.1, Leiden, 1990. For an English 
Gregory of Nyssa describes how the populace of Neocaesarea and the surrounding villages gathered in the city's theatre to celebrate a festival in honor of one of their ancestral gods, who is referred to by the locals within the narrative as "Zeus" but who is characterized by the narrator as a demon. The crush of the crowd of people at the festival becomes unbearable, they pray to Zeus to alleviate their overcrowding, and the pagan demon obliges by sending a plague that decimates the population. When the people realize that their suffering is being caused by their own ancestral "god," they begin to turn to Gregory Thaumaturgus and confess their faith in Christ. Gregory Thaumaturgus then visits the homes of the converts and drives out the plague, and in doing so successfully wins over the rest of the populace to Christianity. ${ }^{2}$

In this final section of the Life, Gregory of Nyssa takes the reader backwards in narrative time to the beginning of Gregory Thaumaturgus's activities in Pontus, ${ }^{3}$ and for that reason it has been suggested that Gregory of Nyssa added this last scene with its description of a pagan festival to the ending of what had been the original version of the Life. ${ }^{4}$ Thus Stephen Mitchell argues that the text, as it now stands, "ends curiously." However, it seems to me that, regardless of whether this festival scene was part of the Life in its original form, its significance is enhanced by the fact that it follows shortly on the heels of the description of Gregory Thaumaturgus's institution of a number of Christian festivals in honor of martyrs. ${ }^{6}$ The Life ends, as it were, with a tale of two kinds of festivals. Moreover, the final festival scene hinges upon a familiar narrative motif: the misconstrual of an ambiguously-phrased utterance such as an oracle or, as in this case, a wish. ${ }^{7}$ Such utterances in literature - especially iterations

translation of the Life as well as of Gregory Thaumaturgus's own works, see St. Gregory Thaumaturgus: Life and Works, tr. M. Slusser (Fathers of the Church, 98), Washington, DC, 1998. Translations throughout here are my own.

2 Life of Gregory Thaumaturgus, 97.1-99.32.

3 For an outline of the Thaumaturge's life and works see St. Gregory Thaumaturgus, tr. Slusser, pp. 1-8. For major studies of the Life and the issues involved in approaching it as a historical source, see R. Van Dam, "Hagiography and History: The Life of Gregory Thaumaturgus," Classical Antiquity, 1.2 (1982), pp. 272-308, and S. Mitchell, "The Life and Lives of Gregory Thaumaturgus," in: Portraits of Spiritual Authority: Religious Power in Early Christianity, Byzantium, and the Christian Orient, ed. J. W. Drijvers, J. W. Watt, Leiden, 1999, pp. 99-138.

4 Thus P. Koetschau, "Zur Lebensgeschichte Gregors des Wunderthäters," Zeitschrift für wissenschaftliche Theologie, 41 (1998), pp. 211-250, at p. 241, cited by Slusser, p. 84 n. 73 .

5 Mitchell, "The Life and Lives," p. 127.

6 Life of Gregory Thaumaturgus, 94.1-27.

7 For the motif of the ill-considered wish in classical literature, see G. Anderson, Fairytale in the Ancient World, London, 2000, pp. 135-137. The most famous example of the misconstrued oracle is of course Herodotus's account of the Delphic Oracle's response to Croesus. For stud- 
of the "be careful what you wish for" motif - tend to carry a lot of dramatic weight. However, to my knowledge, the text of the wish here has not yet been correctly explained. In what follows I describe the background of the scene, how the text of the wish functions across its several semantic levels, and how the entire scene should be more holistically integrated into the Life's thematic structure concerning the transition from pagan to Christian society.

We turn first to the festival scene itself, when the theater becomes so overcrowded that the people pray to Zeus for more space:

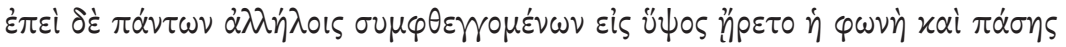

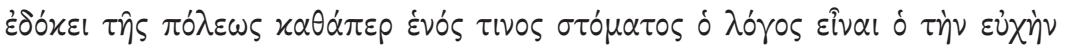

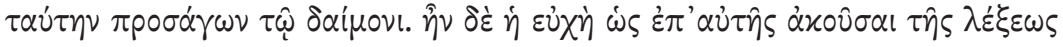

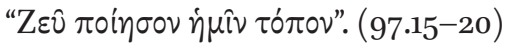

And when, as everyone was acclaiming together, the voice rose up on high, it seemed that the speech presenting this prayer to the demon were coming from the whole city as if from a single mouth. And the prayer, to use the phrase itself, was "Zeus make us space."

Predictably, the "demon" Zeus hears their prayer, but fulfills it in a way contrary to their expectations: he sends a plague that ravages the populace and does, indeed, create more living space for the survivors. In the face of the calamity, described in lurid detail with the obligatory Thucydidean language, the populace turn to Gregory Thaumaturgus for help and declare that they will convert and recognize the one true God. ${ }^{8}$

Thus far, commentators have been content to let Gregory's own narrative

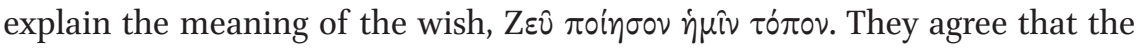
demon Zeus grants the wish by sending the plague. The phrase $\pi$ oin $\sigma 0 v$ i $\mu \hat{i}$

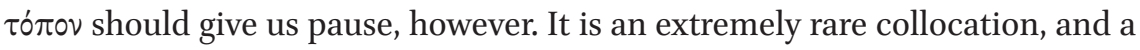
TLG search yields only two hits: our passage in the Life and a homily by Neophytus of Cyprus (12th-13th century). ${ }^{9}$ Neophytus' homily provides a critical

ies that focus on Herodotus's use of the oracle as a narrative device, see E. Barker, "Paging the Oracle: Interpretation, Identity and Performance in Herodotus' 'History," in Greece and Rome, 53.1 (2006), pp. 1-28; and J. Kindt, "Delphic Oracle Stories and the Beginning of Historiography: Herodotus' Croesus Logos," in Classical Philology, 101.1 (2006), pp. 34-51.

8 For the Thucydidean language of the plague description, see Grégoire de Nysse, Éloge de Grégoire le Thaumaturge, éd. Maraval, p. 224, n.1.

9 See Neophytus, Or. 6.136-137, edited by Th. Giagkou and N. Papatriantafyllou-Theodoridi in

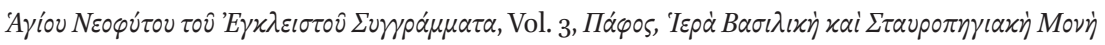

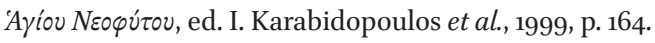


clue, for the passage of his in question is an extended commentary on Isaiah

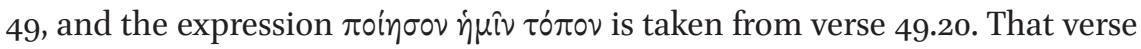
from the Septuagint reads in full as follows:

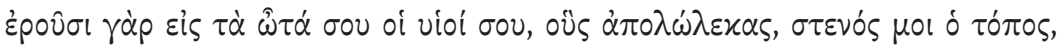

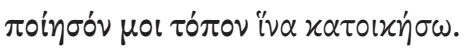

For your sons whom you have lost will say to your ears, this space is too narrow for me, make me space that I may dwell in.

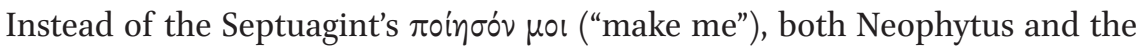
crowd in Neocaesarea in Gregory of Nyssa's narrative give $\pi$ oin $\sigma 0 v$ in $\mu$ iv ("make us"), which explains why no other parallels to their rendering appear in the

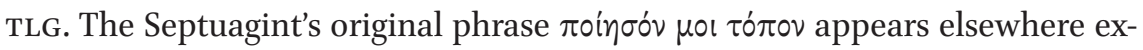
clusively, it must be emphasized, in discussions of this very verse from Isaiah. Moreover, one of those discussions is by Gregory of Nyssa himself, in his Epiphany oration, where he cites Isaiah by name and quotes the second half of

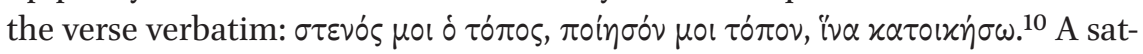
isfactory interpretation of the wish in the Life and of the entire scene involving the conversion of Neocaesarea will need to account for why Gregory of Nyssa echoes the language of Isaiah, language which he knew well and cited explicitly in his oration on Epiphany. It will require a little unpacking in order first to explain the background of this passage in Isaiah, and then to show why Gregory of Nyssa quotes these words in his oration on Epiphany. It will then become clear, finally, why Gregory of Nyssa constructs this final tale of the Life so as to have the unwitting populace of Neocaesarea channel the words of Isaiah.

The relevant section of the Book of Isaiah speaks of Israel as desolate and its people as being in exile in Babylon. ${ }^{11}$ It foretells the role of Cyrus, the anointed

10 For Gregory's Epiphany oration In Diem Luminum, see E. Gebhardt's edition in Gregorii Nysseni Opera, Vol. 9.1, Leiden, 1967, pp. 221-242, with the quotation from Isaiah 49:20 appearing at p. 222.9-10.

For modern commentary on this section of Isaiah see J. Goldingay, D. Payne, A Critical and Exegetical Commentary on Isaiah 40-55, London, 2006. The earliest extant commentary on Isaiah is that of Eusebius; for introduction and translation see J. Armstrong, Eusebius of Caesarea: Commentary on Isaiah, Downers Grove, IL, 2013. Chapters 40 through 55 of Isaiah reflect a different historical context than the previous sections of the book, and are generally recognized as the work of a different author, sometimes called "Second Isaiah." Christian exegetes understood this break in subject and style as the same prophet's transition to a new topic of prophecy; see R. Wilken, Isaiah Interpreted by Early Christian and Medieval Commentators, Grand Rapids, Mich., 2007, pp. 265-266. 
of God (Is. 45.1), who is to conquer Babylon, lead the captives back to Israel, and restore Jerusalem. The idols of the Babylonian gods are overthrown before the true God (46.1). God reminds the people of Israel that what has come to pass has been predicted and brought about by him, lest they attribute it to the idols and graven images they might have taken up in captivity (48.1-5). God has refined his people in the furnace of affliction (48.10), since they had not hearkened to his commandments (48.18). Now, even though Zion is desolate and cries that the Lord has forsaken her (49.14), she is exhorted to lift her eyes up in a circle (49.18) and behold all the people that will come and populate her empty desolation. That land will soon be so filled with inhabitants that their descendants will say, "this space is too narrow for me, make me space that I may dwell in" (49.20). Thanks to the aid of the gentiles, the Israelites will be able to return home and multiply in such numbers that they will be crowded in lands that were formerly desolate.

Gregory of Nyssa's oration for the Day of Lights or Epiphany ${ }^{12}$ begins with a proemium that engages at length with the above passages from Isaiah. Gregory rejoices to see the church overflowing; the congregation is "crowding" the

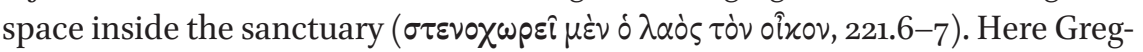
ory is already hinting at the passage in Isaiah that he will soon cite by name further on: Isaiah 49.19 declares that Israel's desolation "will soon be crowded

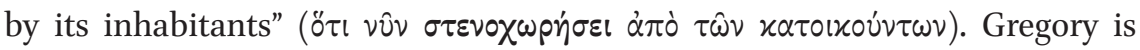
pleased at the sight, in contrast to what he says he feels when his congregation

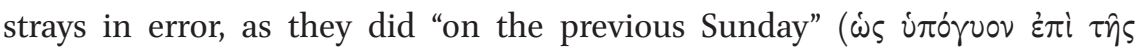

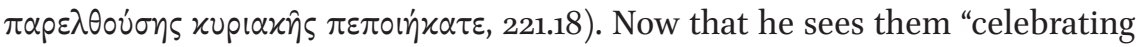
the festival together with their children," he is reminded of the words of Isaiah

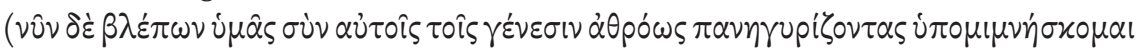
$\lambda \circ \gamma$ iov $\pi \rho \circ \varphi \eta \tau i x \circ \hat{v}, 222.3-5)$. Gregory then quotes two verses related to children in which, according to him, Isaiah foretells in advance "the populous church of

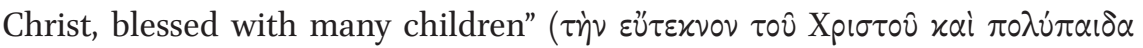
$\pi \rho \circ \alpha \nu \alpha \varphi \omega \nu \omega \hat{\varepsilon} \varepsilon \varkappa \lambda \eta \sigma i \alpha \nu, 222.6-7)$. The first of those verses is Isaiah 6o.8, and

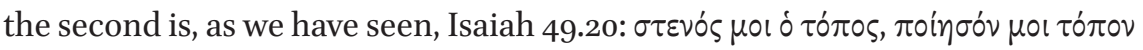

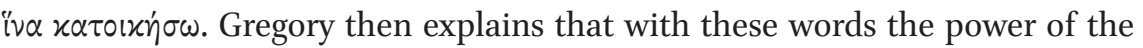
Spirit foretold the ever-expanding church of God, which in years to come would fill the entire world:

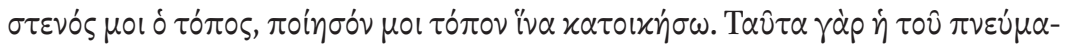

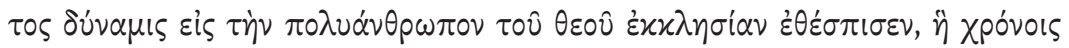




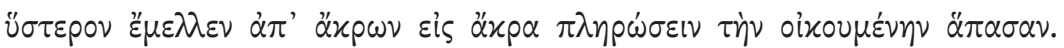
$(222.10-12)$

"This space is too narrow for me, make me space that I may dwell in." For this is what the power of the Spirit prophesied regarding the populous church of God, which in later times would come to fill the entire world from one end to the other.

Here Gregory of Nyssa explicitly interprets Isaiah's phrase "make me space that I may dwell in" as referring to the spread of Christianity throughout the world. In doing so, he is in line with the wider Christian tradition, which saw in several passages in Isaiah, and especially in Chapter 49, an extended prophecy concerning the expansion of Christianity among the non-Jewish "gentiles" of the Mediterranean and Near East. ${ }^{13}$ Beginning in Chapter 49, the Isaiah narrator addresses the "gentiles" or "nations," and later in the book prophecies that they are to be gathered in Zion. The universalism of these passages proved attractive to Christians from an early period. In fact, the Book of Acts depicts Paul and Barnabas in Pisidian Antioch quoting Isaiah 49:6 in order to justify their decision to preach to crowds of all people, Jews and non-Jews alike. Paul and Barnabas claim that this particular verse represents a commandment to spread the gospel among the gentiles (Acts 13:46-47). Such an interpretation of this material in Isaiah took on only greater significance in the following centuries as Christianity expanded. ${ }^{14}$ It became a common motif throughout the exegetical commentaries produced during Late Antiquity to interpret the later passages of Isaiah, especially Chapter 49, as a prophecy regarding the spread of Christianity among all the nations of the world and to understand Zion as referring to the Christian Church itself. ${ }^{15}$ The first verse of the chapter is famously addressed to the "islands" and the "nations," and both Cyril of Alexandria and Theodoret of Cyrus, to use later examples but ones nevertheless representative of the tradition, begin their exegesis of Chapter 49 by noting that with this and the following verses the prophet declares to the gentiles their salvation. ${ }^{16}$

13 Acts 13:44-49.

14 As noted for example by M. Hollerich, Eusebius of Caesarea's Commentary on Isaiah: Christian Exegesis in the Age of Constantine, Oxford, 1999, p. 39: "the gathering in of the Gentiles had of course been a staple of Christian preaching since Paul, but it could claim even greater relevance in the years after $325 . "$

For examples of late ancient exegesis on Isaiah 49, see the passages selected and translated in Wilken, Isaiah Interpreted, pp. 366-379.

For the text of Theodoret's commentary to the beginning of Chapter 49 see Théodoret de Cyr, Commentaire sur Isaïe, t. III, éd. et tr. J.-N. Guinot (sc, 315), Paris, 1984, p. 72.186-187: 
Such then was the Christian understanding of Isaiah 49 that would have likely been familiar to Gregory of Nyssa and his audience. Why however does Gregory choose to draw on this exegetical tradition of Isaiah at this particular point in the Epiphany oration? To what scenario was Gregory responding, and why did he think of these verses from Isaiah here? We need to consider the original context of the oration itself, which has been dated to $383 .{ }^{17}$ Gregory contrasts his current feelings with the way the congregation behaved the previous Sunday, when they were "wandering in their external error" ( $\tau \dot{\eta} \nu$ है $\xi \omega \pi \lambda \alpha^{\alpha} \nu \eta \nu$

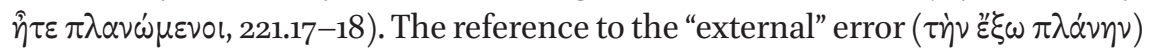
must refer to something having to do with "pagan" culture. ${ }^{18}$ With Epiphany celebrated on January 6, the events "of the previous Sunday" to which he refers would most probably have had some connection to the festivities of the Kalends of the New Year, which were a popular target of Christian moralizing. ${ }^{19}$ Gregory's joy derives from seeing his congregation returning from a pagan festival and celebrating a Christian festival. The verse from Isaiah is useful to his purpose because it describes how Israel is to be repopulated as the Israelites return from their exile in a "pagan" land. Like the Israelites of old, Gregory's congregation had returned from being "occupied" with pagan festivities, and like the swelling generations of the Israelites they crowded the building, embodying the expansion of the Church that Isaiah had prophesied.

For Gregory these verses were apropos to a situation in which he saw, as it were, the history of the Church in microcosm: on the previous Sunday the people had celebrated a pagan festival, but on the current Sunday they have come together to celebrate the festival of Christ's baptism. The Isaiah verse - "this space is too narrow for me, make me space that I may dwell in" - signified for Gregory the spread of the Church among the gentiles and the transformation of a pagan civilization, together with its customs, to a new Christian society.

Gregory's use of this verse in his Epiphany oration can thus gloss the appearance of the same verse in the Life, when the festival crowd unwittingly channels Isaiah in praying to Zeus to "make us space." Again, we must recall that this particular formulation features only one other time in the TLG, and in a

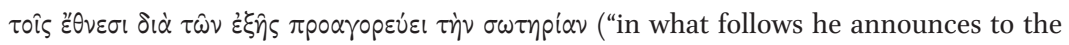
gentiles their salvation"). For translation of Cyril's similar commentary to the same chapter, see Wilken, Isaiah Interpreted, p. 367, citing Cyril at PG 70, col. ${ }_{1033} \mathrm{D}-1041 \mathrm{~A}$.

17 For dating and background see J. Rexer, Die Festtheologie Gregors von Nyssa: ein Beispiel der reichskirchlichen Heortologie, Frankfurt, 2002, pp. 97-102.

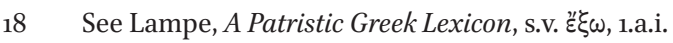

19 For these orations against the Kalends, as well as a new argument that they may have elicited Libanius' own oration on the Kalends (Or. 9) as a response, see F. Graf, "Fights about Festivals: Libanius and John Chrysostom on the Kalendae Ianuariae in Antioch," Archiv für Religionsgeschichte, 13 (2012), pp. 175-186. 
homily discussing Isaiah at that. We should note as well the appearance in the Life of the word $\sigma \tau \varepsilon v \circ \chi \omega \rho \circ \nu \mu \varepsilon \dot{v} \omega \nu$ (97.10), a word which also features in the Isa-

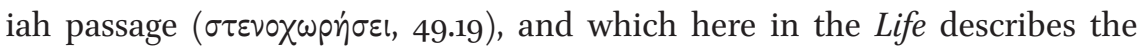
"crowding" of the festival goers, just as it was also used in Gregory's Epiphany oration to describe the crowded festival congregation ( $\sigma \tau \varepsilon \nu 0 \chi \omega \rho \varepsilon i \hat{\imath} \mu \dot{\varepsilon} \nu \dot{\delta} \lambda \alpha \dot{\zeta} \varsigma$, 221.4). Indeed, the fact that the same word for "crowding" ( $\sigma \tau \varepsilon v 0 \chi \omega \rho \varepsilon i)$ occurs in the Isaiah verse, the homily, and the Life, and in close connection again in all three texts to the prayer to "make space," presents, to my mind at least, the strongest argument for seeing the Isaiah verse as the hermeneutic key for understanding the prayer of the crowd of Neocaesarea, as well as the Life's conversion narrative in general.

According to the internal logic of the Life's narrative, the crowd's shout

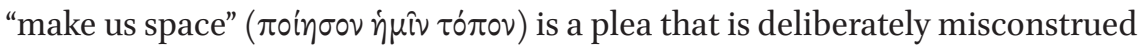
by the "demon" to which it is addressed. The plague which he sends them to provide the space they requested leads to the mass conversion of the populace to Christianity. They turn to Gregory Thaumaturgus for assistance and pronounce their faith in the one true God. Gregory Thaumaturgus then visits the homes of those afflicted by the plague and wards off the effects of the demon. The populace abandons their pagan customs, including the consultation of oracles, animal sacrifice, and idolatry. With the "error" of idolatry refuted ( $\tau \hat{\eta} \varsigma$ $\left.\pi \varepsilon p i \tau \dot{\alpha} \varepsilon \varepsilon^{\prime \prime} \delta \omega \lambda \alpha \pi \lambda \alpha^{\prime} \nu \eta \varsigma, 99.27-28\right)$, the people all convert to the name of Christ. Here Gregory of Nyssa uses the same word for pagan "error" that he uses in the Epiphany oration to describe the festivities of the New Year Kalends celebrated by his congregation on the previous Sunday (221.17). As the Life's account of the pagan festival falls shortly after the description of Gregory Thaumaturgus's institution of martyr festivals (94), we seem invited to read these festival scenes against one another. As with the juxtaposition of a Christian and a pagan festival in the Epiphany oration, so here Gregory of Nyssa uses the martyr festivals and the Zeus festival to mark key points in a conversion narrative. Once again, they represent in microcosm the conversion of the gentiles and the transformation of pagan society. The pagan festival crowd unwittingly offer a nearquotation of a verse that was deeply connected to Christian narratives of the universal conversion of the gentiles. This misguided prayer then leads directly to the mass conversion of a gentile society. Gregory of Nyssa has the festival crowd foreshadow their own conversion.

Moreover, Gregory of Nyssa brings this mini-narrative of conversion full circle by having Gregory Thaumaturgus's actions allude to further soteriological verses from Isaiah. Gregory of Nyssa describes how the trappings of their old religion were abandoned as the people of Neocaesarea turned to Gregory Thaumaturgus and Christianity: 


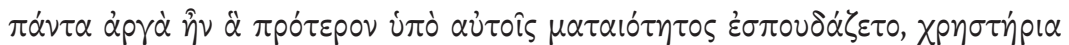

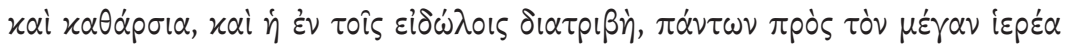

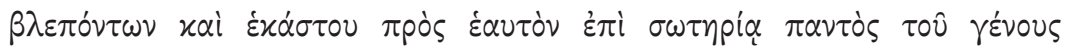

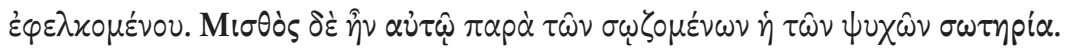
$\left(99.15^{-20}\right)$

And everything that their vanity had earlier practiced lay inert, oracles and expiatory sacrifices and time spent among the idols, as all looked to the great priest and each was drawn to him for the salvation of the whole race. His reward from those he saved was the salvation of their souls.

We can compare this description of Gregory Thaumaturgus, whose "reward" is the spiritual salvation of those he saved from the plague, with another verse from Isaiah, in this case a prophecy concerning the coming of the awaited savior:

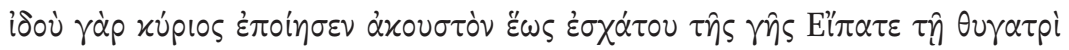

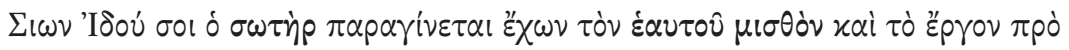

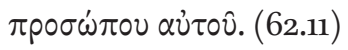

Behold for the Lord made it heard to the ends of the earth, "Tell the daughter of Zion, behold your savior is at hand, bearing with him his own reward and his work before his sight."

In the pregnant phrasing of the text of the Septuagint, the "savior" of the prophecy comes already "bearing his own reward." In "saving" the people from the plague and thus having secured their spiritual "salvation," Gregory Thaumaturgus is likewise already in possession of his "reward." By delivering the people of Neocaesarea from their former idolatry, Gregory Thaumaturgus was made to evoke the savior prophesied in Isaiah, who is to deliver the Israelites from idolatrous Babylon. The "savior" of Isaiah 62:11 was naturally interpreted by Christians as referring to the coming of Christ. ${ }^{20}$ Thus Gregory Thaumaturgus plays the role of a Christ-like figure in bringing about the conversion en masse of the city's population, as indeed he does throughout his activities in Neocaesarea.

Moreover, the way Gregory of Nyssa has made his hero recall this verse of Isaiah seems also to draw on another aspect of the traditions of Christian commentary on this verse. Turning again to a slightly later commentator, we find

$20 \quad$ See Wilken, Interpreting Isaiah, pp. 482-487. 
that Cyril of Alexandria interprets the phrase "bearing with him his own reward" as referring specifically to the spiritual gifts that Jesus conferred on his disciples. As examples of these spiritual gifts, Cyril explicitly cites the ability to cure diseases and drive out unclean spirits. ${ }^{21}$ This is, of course, exactly what Gregory Thaumaturgus has just accomplished in delivering the people of Neocaesarea from the plague and turning them from their worship of the demon who sent that plague. Gregory Thaumaturgus's "reward," namely the salvation of the people he saved from the plague, may thus also allude to an understanding of Isaiah's "reward" as referring to those same spiritual gifts that enabled Gregory Thaumaturgus to save those people in the first place.

This final episode in the Life of Gregory Thaumaturgus has seemed out of place to some scholars. As noted above, Mitchell writes that in concluding with such a scene, the Life "ends curiously."22 We have seen however that the key to understanding this passage lies in the ambiguously-worded prayer uttered by the people of Neocaearea, a prayer which drives the entire plot of the episode. The festival crowd is made to cite a verse which held particular importance for the author of the Life, as we have seen from Gregory of Nyssa's oration for Epiphany. Gregory Thaumaturgus, in delivering the people from the plague as well as from their idolatry, is depicted with soteriological language from Isaiah. Gregory of Nyssa has both the people of Neocaesarea and then the actions of Gregory Thaumaturgus himself evoke passages from Isaiah that were charged with meaning for the Christian tradition, and in doing so he inscribes what might have otherwise seemed a "curious" episode into the Christian narrative of universal conversion and salvation. ${ }^{23}$

\footnotetext{
21 See Ibid., p. 485, citing PG 70, col. 1380C14-D2.

22 See above n. 5.

23 The research for this paper was conducted during a Junior Fellowship in Byzantine Studies at Dumbarton Oaks, as well as at the Institut für Byzantinistik und Neogräzistik at the University of Vienna. It is a pleasure to express my gratitude to both institutions. My warm thanks go also to Basil Lourié for his interest, patience, and insightful assistance.
} 